\title{
Growth, Physiological and Molecular Responses of Cotton (Gossypium arboreum L.) under NaCl Stress
}

\author{
Sameera Hassan, Muhammad Bilal Sarwar, Sajjad Sadique, Bushra Rashid*, Beenish Aftab, \\ Bahaeldeen Babiker Mohamed, Tayyab Husnain
}

Center of Excellence in Molecular Biology, University of the Punjab, Lahore, Pakistan

Email: ${ }^{*}$ bushra.cemb@pu.edu.pk

Received 18 January 2014; revised 18 February 2014; accepted 28 February 2014

Copyright (C) 2014 by authors and Scientific Research Publishing Inc.

This work is licensed under the Creative Commons Attribution International License (CC BY).

http://creativecommons.org/licenses/by/4.0/

c) (i) Open Access

\begin{abstract}
Salinity is one of the most serious growth limiting factor, therefore, no longer being ignored. Although, cotton is fairly salt tolerant; its sensitivity at crop stand and yield is affected. This study is planned to identify the growth, physiological and molecular parameters in local cotton varieties FDH 171 and FDH 786 under NaCl stress. There was 100\% seed germination but hypocotyl length was reduced at increasing level of $\mathrm{NaCl}$. Plant height, fresh and dry biomass were reduced as the plants were subjected to increased stress of $\mathrm{NaCl}$. Stomatal conductance, transpiration and photosynthetic rate and ionic imbalance were found to be reduced under the gradual increase in $\mathrm{NaCl}$ stress and affected the plant's overall physiological processes. PCR product of AtNHX3 has been identified in stressed and non-stressed plants. Thus, the genotypes FDH 171 \& FDH 786 were found tolerant to adoption of salt stress and could be used as a source in crop improvement.
\end{abstract}

\section{Keywords}

Salt Stress; Gossypium arboretum; Cotton; Gas Exchange Parameters; Growth Analysis

\section{Introduction}

While salinity is one of the major environmental challenge and it causes a substantial crop revenue loss [1]. Many factors such as low rainfall and higher surface evaporation, salty water irrigation, contamination of water and improper agricultural practices are mainly responsible for salinity [2]. Salt stress leads to alterations to physiological responses [3], integrity of cellular membranes and activity of various enzymes are unjustified [4] and

"Corresponding author. 
impaired nutrient uptake [5]. Different plant developmental stages such as seed germination, root enlargement and expansion, leaf area, shoot development and seed production are adversely affected due to salt stress which results in significant decrease in biomass production [6]. Photosynthesis is one of major physiological processes which are adversely affected due to restricted functioning of stomata [7]. Nutrient imbalance reduces the plant development by disturbing the accessibility and transportation of nutrients within plants. $\mathrm{Na}^{+}$and $\mathrm{Cl}^{-}$compete with other nutrients including $\mathrm{K}^{+}, \mathrm{Ca}^{2+}$, and $\mathrm{NO}^{3-}$ and it may cause imbalanced distribution and these acts negatively on biophysical and/or metabolic processes [8].

Plant species have adapted a number of defense mechanisms to combat with salinity as they have developed structures or mechanisms which support to remove and/or compartmentalize ions. Some plants exclude excessive salts from leaves through salt secreting glands [9], while, others utilize the normal existence of vacuoles to accumulate ion toxicity [10].

Cotton (Gossypium hirsutum L.) occupies a pivotal position in Pakistan's economy by providing fiber, food and fuel. The diploid cotton species are not only the reservoir of improved agronomic and fiber traits but also offer better opportunities to study the gene structure and function [11]. Salt tolerance mechanism is not completely understood, but we can predict the performance of crops by studying various growth factors, physiological adaptations [3] and gene functions [12] [13]. Hence, present study was conducted to pre-screen G. arboreum genotypes FDH 171 and FDH 786 against $\mathrm{NaCl}$ stress to identify the growth, physiological and molecular factors.

\section{Materials and Methods}

\subsection{Seed Germination, Growth Conditions and NaCl Stress Treatment}

The experiment was performed in green house based on Complete Randomized Design to investigate the response of two local verities of Gossypium arboreum FDH 171 and FDH 786. Seeds of each variety were delinted, sterilized and placed onto sterile filter papers in Petri plates which were supplemented with 100, 150 and $200 \mathrm{mM} \mathrm{NaCl}$ and kept in dark at $30^{\circ} \mathrm{C}$. Seeds incubated without $\mathrm{NaCl}$ were considered as control. Seed germination percentage was calculated

$$
\text { Germination Percentage }=(\text { No.of seeds germinated }) /(\text { Total No.of seeds }) \times 100
$$

Germinated seeds were sown in plastic pots (7” $\times$ 8”) containing soil mixture [14]. $\mathrm{NaCl}$ stress was imposed when 3 - 4 true leaves appeared. This was applied with irrigation water after every second day and continued for 3 weeks [15]. Plants irrigated without $\mathrm{NaCl}$ treatment were considered as control. Data were collected for plant growth, physiological and molecular variables.

\subsection{Morphological Studies}

\section{Plant Height}

Growth attributes were measured for salt stressed and control plants as previously described [16]. Initial height of seedling was measured from soil surface to apex before application of $\mathrm{NaCl}$ stress. Then after three weeks of salt stress treatment, final height of the plant was measured. Percent increase in plant height was calculated as:

$$
\text { (Final Height }- \text { initial height }) /(\text { initial height }) \times 100
$$

\subsection{Physiological Attributes}

\subsubsection{Plant Biomass}

Five normal seedlings were harvested at random after salt treatments. Roots were washed with distilled water and fresh weight (FW) was expressed as gm per plant. Then plants were wrapped in brown papers and dried for 48 hours at $80^{\circ} \mathrm{C}$ and dry weight (DW) was expressed as gm per plant. Percent reduction in biomass was observed as:

$$
(\mathrm{FW}-\mathrm{DW}) / \mathrm{FW} \times 100
$$

\subsubsection{Gas Exchange Parameters}

Gas exchange parameters such as net photosynthesis rate by unit of leaf area $\left(\mathrm{Pn}, \mu \mathrm{mol} \mathrm{CO}_{2} \mathrm{~m}^{-2} \cdot \mathrm{s}^{-1}\right)$, transpira- 
tion rate $\left(\mathrm{E}, \mu \mathrm{mol} \mathrm{H} \mathrm{H} \mathrm{m}^{-2} \cdot \mathrm{s}^{-1}\right)$, and the stomatal conductance to water vapor $\left(\mathrm{C}, \mu \mathrm{mol} \cdot \mathrm{m}^{-2} \cdot \mathrm{s}^{-1}\right)$ were measured from control and salt treated plants' leaves with a handheld IRGA, gas exchange system (CI-340 Bioscientific Ltd., UK) at midday of sunshine.

\subsubsection{Ion Accumulation}

$\mathrm{Na}^{+}, \mathrm{K}^{+}$and $\mathrm{Cl}^{-}$ion content were determined by following the procedure [17]. About $1 \mathrm{~g}$ of dried leaves was taken into $100 \mathrm{ml}$ Pyrex digestion tube with $10 \mathrm{ml}$ of (acid) nitric and per chloric (2:1) mixture. After preliminary digestion, tubes were placed in a cold block-digester chamber $\left(150^{\circ} \mathrm{C}-235^{\circ} \mathrm{C}\right)$ until clear colorless solution appeared. $\mathrm{Na}^{+}$and $\mathrm{K}^{+}$contents were determined with a flame photometer. Chloride concentration was determined by silver nitrate titration. Digested plant sample $(10 \mathrm{ml})$ with 4 drops of potassium chromate solution titrated against $0.05 \mathrm{~N}$ silver nitrate until a permanent reddish-brown color appeared.

\subsection{Molecular Analysis}

Total RNA Extraction and PCR Amplification of AtNHX3 Gene

Total RNA was extracted from $\mathrm{NaCl}$ stressed and control plants and quantified with Nanodrop (ND-1000) at A260/280 and A260/230. cDNA was synthesized and PCR product for AtNHX3 was amplified using Forward (5'-GTACCCAAGGCCAGTCAG-3)' and Reverse primer (5-CACTCCATTGCGGAACAC-3'). Reaction mixture contained $2 \mu \mathrm{l}$ cDNA, $2 \mu \mathrm{l}$ 10X PCR buffer, $2 \mu \mathrm{l}$ each primer $(10 \mu \mathrm{M}$ each), $1 \mu \mathrm{l}$ dNTPs $(10 \mathrm{mM}), 1.5$ $\mu 1 \mathrm{MgCl}_{2}(25 \mathrm{mM}), 0.2 \mu \mathrm{l} 5$ units Taq DNA. PCR conditions were: Denaturation at $94^{\circ} \mathrm{C}$ for $3 \mathrm{~min}, 35$ cycles of $94^{\circ} \mathrm{C}$ for $30 \mathrm{sec}, 55^{\circ} \mathrm{C}$ for $30 \mathrm{sec}$, and $72^{\circ} \mathrm{C}$ for $30 \mathrm{sec}$, final extension at $72^{\circ} \mathrm{C}$ for 7 min and held at $25^{\circ} \mathrm{C}$. Product was run on $1 \%$ Agarose in $0.5 \mathrm{X}$ TAE and examined under UV.

\subsection{Statistical Analysis}

The experiment was arranged in completely randomized design with two factor factorial arrangement. Data are the means of 5 replicates, and results were determined using analysis of variance (ANOVA) via Statistix software. Variation among treatment means were compared using least significant difference (LSD).

\section{Results}

\subsection{Seed Germination}

In this experiment germination percentage of both FDH 171 and FDH 786 was 100\%, however hypocotyl length was decreased for both the genotypes as salinity level increased (Table 1). ANOVA and means analysis shows, a significant interaction between salt stress and hypocotyls length of both genotype $(P \leq 0.05)$ (Tables 2 , 3). In FDH 171 under control condition, average hypocotyl length was $39 \mathrm{~mm}$ which was continued to decrease to $31.75,17.87$ and $14.37 \mathrm{~mm}$ as the concentration of $\mathrm{NaCl}$ was increased to $100 \mathrm{mM}, 150 \mathrm{mM}$ and $200 \mathrm{mM}$ respectively. While in FDH 786, hypocotyl length was found to be maximum $64.85 \mathrm{~mm}$ under control conditions and it was reduced as $42 \mathrm{~mm}$ and $27.25 \mathrm{~mm}$ at $100 \mathrm{mM}$ and $150 \mathrm{mM} \mathrm{NaCl}$ and at $200 \mathrm{mM}$ the length was decreased to $9.87 \mathrm{~mm}$.

\subsection{Morphological Studies}

\section{Increase in Plant Height (\%)}

Plants were growing with variable length under control and salt stressed condition. Initial height of seedlings was in the range of 6.8 to $7.7 \mathrm{~cm}$ for FDH 171 and 8.5 to $8.8 \mathrm{~cm}$ for the variety FDH 786 (Table 1). The \% increase in plant height is 18.68 in the control conditions but the same was reduced as the concentration of $\mathrm{NaCl}$ was increased such as values are 12.9, 11.45 and 6.75 at 100,150 and $200 \mathrm{mM} \mathrm{NaCl}$ respectively. Initial height of plant treated with $200 \mathrm{mM} \mathrm{NaCl}$ was $7.7 \mathrm{~cm}$ which was greater than grown under control conditions i.e. $6.85 \mathrm{~cm}$ but after treatment of $200 \mathrm{mM}$ salt, \% increase in seedling was less i.e. 7.75 as compared to the control seedling which was increased at the rate 18.68. Similarly initial height of plants before treatment of 100 and $150 \mathrm{mM}$ $\mathrm{NaCl}$ was 6.65 and $6.23 \mathrm{~cm}$ respectively but the \% increase in plant height was less i.e. 12.9 and 11.45 respectively after treatment. Similarly for the variety FDH 786, initial height of plants was 8.5, 7.4, 8.82 and $8.87 \mathrm{~cm}$ but after treatment of $\mathrm{NaCl}$, plant height was increased at the rate of $10.47 \%$ at $100 \mathrm{mM}, 7.48 \%$ at $150 \mathrm{mM}$ and 
Table 1. Growth indicators of cotton varieties FDH 171 and FDH 786.

\begin{tabular}{|c|c|c|c|c|c|}
\hline \multirow{2}{*}{ Cotton Cultivars } & \multirow{2}{*}{$\mathrm{NaCl}$ Stress mM } & \multirow{2}{*}{ Hypocotyl length } & \multicolumn{2}{|c|}{ Plant Height (cm) } & \multirow{2}{*}{$\begin{array}{c}\text { \% Increased Plant } \\
\text { Height }\end{array}$} \\
\hline & & & Initial Height & Final Height & \\
\hline \multirow{4}{*}{ FDH-171 } & Control & $64.47 \mathrm{~A}$ & $8.5 \mathrm{AB}$ & $10.01 \mathrm{~A}$ & $17.64 \mathrm{~A}$ \\
\hline & 100 & $42.28 \mathrm{~B}$ & 7.4 CD & $8.07 \mathrm{CD}$ & $10.47 \mathrm{~A}$ \\
\hline & 150 & $27.62 \mathrm{C}$ & $8.82 \mathrm{~A}$ & $9.48 \mathrm{AB}$ & $7.48 \mathrm{D}$ \\
\hline & 200 & $9.73 \mathrm{E}$ & $8.87 \mathrm{~A}$ & $9.42 \mathrm{AB}$ & $5.41 \mathrm{E}$ \\
\hline \multirow{4}{*}{ FDH-171 } & Control & 39 B & 6.85 CDE & $8.13 \mathrm{CD}$ & $18.68 \mathrm{~A}$ \\
\hline & 100 & 31.75 C & $6.65 \mathrm{DE}$ & $7.51 \mathrm{CD}$ & $12.9 \mathrm{~B}$ \\
\hline & 150 & $17.69 \mathrm{D}$ & $6.23 \mathrm{E}$ & $6.95 \mathrm{D}$ & $11.45 \mathrm{C}$ \\
\hline & 200 & 14.37 DE & $7.7 \mathrm{BC}$ & 8.52 BC & $6.75 \mathrm{D}$ \\
\hline
\end{tabular}

Means followed by different alphabet are different at 5\% level of significance based on least significant difference test (LSD), while those followed by same letters are statistically non-significant.

$5.41 \%$ at $200 \mathrm{mM} \mathrm{NaCl}$. Results concluded that as the concentration of $\mathrm{NaCl}$ is increased, the height of plants is reduced.

\subsection{Physiological Attributes}

\subsubsection{Plant Biomass}

Plant biomass was variable for both varieties at different salinity levels. It was reduced as 74 and $73 \%$ in FDH 171 and FDH 786 respectively under control condition. As NaCl was applied (100, 150 and $200 \mathrm{mM}$ ) to the variety FDH 171 its biomass was reduced at the rate of 77, 78.2 and 81\% (Figure 1). Same pattern \% reduction in biomass was observed in FDH 786 such as 75, 78 and 78.7\% at 100, 150 and $200 \mathrm{mM} \mathrm{NaCl}$ respectively. Overall \% reduction in biomass was less in FDH 786 as compared to FDH 171. However both the varieties are significantly different under $\mathrm{NaCl}$ stress (Tables 2, 3).

\subsubsection{Gas exchange Parameters}

Application of $\mathrm{NaCl}$ reduced the overall photosynthetic rate in both the varieties (Figure 2); however the difference between the varieties was not significant (Tables 2, 3). Transpiration rate was decreased when both the varieties were subjected to salt stress (Figure 2(a)). In FDH 171, transpiration rate was $0.89 \mu \mathrm{mol} \cdot \mathrm{m}^{-2} \cdot \mathrm{s}^{-1}$ under control condition and as the plants were subjected to $\mathrm{NaCl}$ stress $(100,150$ and $200 \mathrm{mM}$ ), value was decreased as $0.7,0.61$ and $0.52 \mu \mathrm{mol} \cdot \mathrm{m}^{-2} \cdot \mathrm{s}^{-1}$ respectively. Likewise in FDH 786, transpiration rate was $1.15 \mu \mathrm{mol} \cdot \mathrm{m}^{-2} \mathrm{~s}^{-1}$ without salt stress and the rate was decreased as $1.0,0.87$ and $0.70 \mu \mathrm{mol} \cdot \mathrm{m}^{-2} \cdot \mathrm{s}^{-1}$ as the salt stress was imposed to 100,150 and $200 \mathrm{mM}$ respectively. Although both the varieties were significantly different at different levels of $\mathrm{NaCl}$ stress (Tables 2, 3) but transpiration rate was lower in FDH 171. Stomatal conductance under control condition was recorded as $2.12 \mu \mathrm{mol} \cdot \mathrm{m}^{-2} \cdot \mathrm{s}^{-1}$ and $1.99 \mu \mathrm{mol} \cdot \mathrm{m}^{-2} \cdot \mathrm{s}^{-1}$ in FDH 171 and FDH 786 respectively (Figure 2(b)). Values of stomatal conductance were 2.10, 1.58 and $1.52 \mu \mathrm{mol} / \mathrm{m} 2 / \mathrm{s}$ under salinity level 100, 150 and $200 \mathrm{mM}$ respectively in FDH 171. The values observed in FDH 786 were $1.89,1.28$ and $1.11 \mu \mathrm{mol} \cdot \mathrm{m}^{-2} \cdot \mathrm{s}^{-1}$ as $\mathrm{NaCl}$ stress was 100,150 and $200 \mathrm{mM}$ respectively. Both the varieties and different levels of $\mathrm{NaCl}$ have no significant difference among each other (Tables 2, 3). Photosynthesis was $12.15 \mu \mathrm{mol} \cdot \mathrm{m}^{-2} \mathrm{~s}^{-1}$ in FDH 171 and $12.02 \mu \mathrm{mol} \cdot \mathrm{m}^{-2} \cdot \mathrm{s}^{-1}$ in FDH 786 under control conditions that was decreased in FDH 171 to $11.23,10.98$, and $6.9 \mu \mathrm{mol} \cdot \mathrm{m}^{-2} \cdot \mathrm{s}^{-1}$ as $\mathrm{NaCl}$ was applied 100,150 and $200 \mathrm{mM}$ respectively (Figure 2(c)). Similar pattern of reduction in photosynthesis was observed in FDH 786 such as $11.03,10.48$ to $10.17 \mu \mathrm{mol} \cdot \mathrm{m}^{-2} \cdot \mathrm{s}^{-1}$ under $\mathrm{NaCl}$ stress 100, 150 and $200 \mathrm{mM}$ respectively. Variation among treatments is significant.

\subsubsection{Ion Accumulation}

$\mathrm{Na}^{+}$and $\mathrm{Cl}^{-}$concentration was more as $\mathrm{NaCl}$ was increased in both the varieties (Figure 3). Accumulation of $\mathrm{Na}^{+}$was less as compared to $\mathrm{K}^{+}$in control plants. Comparative study indicates that the salt stress increased the $\mathrm{Na}^{+}$and $\mathrm{Cl}^{-}$contents, low $\mathrm{K}^{+}$content in both the genotypes (Tables 2, 3). In FDH 786, accumulation of $\mathrm{Na}^{+}$was less $\left(0.025 \mathrm{mg} \cdot \mathrm{g}^{-1} \mathrm{DW}\right)$ in the control plants as compared to the salt stressed. As the higher amount of salt was 
Table 2. Mean value of physiological studies of cotton varieties FDH 171 and FDH 786 under NaCl stress.

\begin{tabular}{cll}
\hline Trait & & Cultivars \\
\cline { 2 - 3 } & FDH 786 & FDH 786 \\
\hline Hypocotyl length & $36.058 \mathrm{~A}$ & $25.399 \mathrm{~B}$ \\
Fresh Weight & $1.0387 \mathrm{~A}$ & $0.9440 \mathrm{~B}$ \\
Dry Weight & $0.2168 \mathrm{~B}$ & $0.2329 \mathrm{~A}$ \\
$\mathrm{Na}^{+}$ & $0.0366 \mathrm{~A}$ & $0.0237 \mathrm{~B}$ \\
$\mathrm{Cl}^{-}$ & $0.3867 \mathrm{~B}$ & $0.7788 \mathrm{~A}$ \\
$\mathrm{~K}^{+}$ & $0.0148 \mathrm{~A}$ & $0.0163 \mathrm{~A}$ \\
Transpiration (E) & $0.9567 \mathrm{~A}$ & $0.6923 \mathrm{~B}$ \\
Stomatal Conductance & $1.7520 \mathrm{~B}$ & $1.7954 \mathrm{~B}$ \\
Photosynthesis (PN) & $10.976 \mathrm{~A}$ & $10.522 \mathrm{~A}$ \\
\hline
\end{tabular}

Means followed by different alphabet are different at $5 \%$ level of significance based on least significant difference test (LSD), while those followed by same letters are statistically non-significant.

Table 3. Analysis of variance of physiological and biochemical analyses of cotton varieties FDH-171 and FDH-786 under $\mathrm{NaCl}$ stress.

\begin{tabular}{|c|c|c|c|c|c|}
\hline Trait & SOV & DF & SS & MS & $\mathrm{F}$ \\
\hline \multirow{3}{*}{ Hypocotyl length } & Cultivars & 1 & 660.96 & 660.96 & $36.87^{* *}$ \\
\hline & Treatments & 3 & 5240.79 & 1746.93 & $97.43^{* *}$ \\
\hline & Cultivars $\times$ Treatments & 3 & 589.35 & 196.45 & $10.96^{* *}$ \\
\hline \multirow{3}{*}{ Fresh Weight } & Cultivars & 1 & 0.05218 & 0.05218 & $14.27^{* *}$ \\
\hline & Treatments & 3 & 0.02159 & 0.00720 & 1.97 \\
\hline & Cultivars $\times$ Treatments & 3 & 0.28553 & 0.09518 & $26.03^{* *}$ \\
\hline \multirow{3}{*}{ Dry Weight } & Cultivars & 1 & 0.00152 & 0.00152 & $7.48^{*}$ \\
\hline & Treatments & 3 & 0.01512 & 0.00504 & $24.75^{* *}$ \\
\hline & Cultivars $\times$ Treatments & 3 & 0.01366 & 0.00455 & $22.37^{* *}$ \\
\hline \multirow{3}{*}{$\mathrm{Na}+$} & Cultivars & 1 & 0.00098 & 9.782 & $32.98^{* *}$ \\
\hline & Treatments & 3 & 0.00184 & 6.149 & $20.73^{* *}$ \\
\hline & Cultivars $\times$ Treatments & 3 & 0.00007 & 2.194 & 0.74 \\
\hline \multirow{3}{*}{ Cl- } & Cultivars & 1 & 0.89443 & 0.89443 & $17.56^{* *}$ \\
\hline & Treatments & 3 & 4.55020 & 1.51673 & $29.78^{* *}$ \\
\hline & Cultivars $\times$ Treatments & 3 & 0.96108 & 0.32036 & $6.29^{*}$ \\
\hline \multirow{3}{*}{$\mathrm{K}+$} & Cultivars & 1 & 1.450 & 1.450 & 1.92 \\
\hline & Treatments & 3 & 2.599 & 8.665 & $11.45^{* *}$ \\
\hline & Cultivars $\times$ Treatments & 3 & 1.519 & 5.064 & $6.69^{*}$ \\
\hline \multirow{3}{*}{ Transpiration Rate (E) } & Cultivars & 1 & 0.40648 & 0.40648 & $76.50^{* *}$ \\
\hline & Treatments & 3 & 0.43777 & 0.14592 & $27.46^{* *}$ \\
\hline & Cultivars $\times$ Treatments & 3 & 0.01711 & 0.00570 & 1.07 \\
\hline \multirow{3}{*}{$\begin{array}{c}\text { Stomatal } \\
\text { Conductance } \\
\text { (C) }\end{array}$} & Cultivars & 1 & 0.01096 & 0.01096 & 0.36 \\
\hline & Treatments & 3 & 2.85291 & 0.95097 & 31.28 \\
\hline & Cultivars $\times$ Treatments & 3 & 0.03430 & 0.01143 & 0.38 \\
\hline \multirow{3}{*}{$\begin{array}{l}\text { Photosynthesis } \\
\text { (Pn) }\end{array}$} & Cultivars & 1 & 1.1979 & 1.19790 & 0.88 \\
\hline & Treatments & 3 & 28.3620 & 9.45400 & $6.97^{*}$ \\
\hline & Cultivars $\times$ Treatments & 3 & 9.5300 & 3.17665 & 2.34 \\
\hline
\end{tabular}

", denotes significant differences at $5 \%$ probability level $(\mathrm{P} \leq 0.05) ;{ }^{* *}$, denotes significant differences at $1 \%$ probability level $(\mathrm{P} \leq 0.01)$.

applied, it directly enhanced the $\mathrm{Na}^{+}$content up to $0.0517 \mathrm{mg} \cdot \mathrm{g}^{-1} \mathrm{DW}$. Same kind of increasing pattern was viewed in FDH 171 however the difference remained significant. No significant difference was found for $\mathrm{K}^{+}$ buildup in both varieties $(\mathrm{p} \leq 0.05)$ (Tables 2,3$)$. It showed negative correlation with the increasing salt and higher accumulation of $\mathrm{Na}^{+}$raised the inclusion of $\mathrm{Cl}^{-}$significantly. 


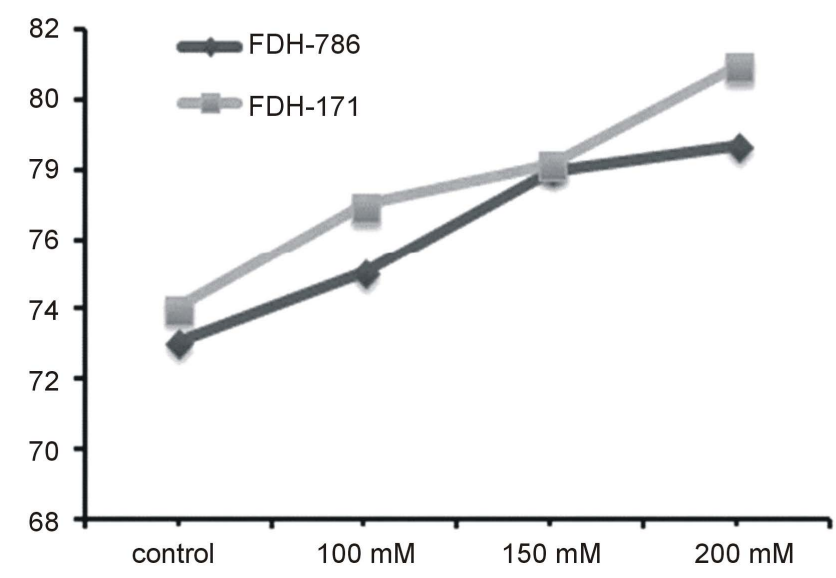

Figure 1. \% Reduction in plant biomass. Each value is mean of five replicates and vertical bars give standard error of mean.
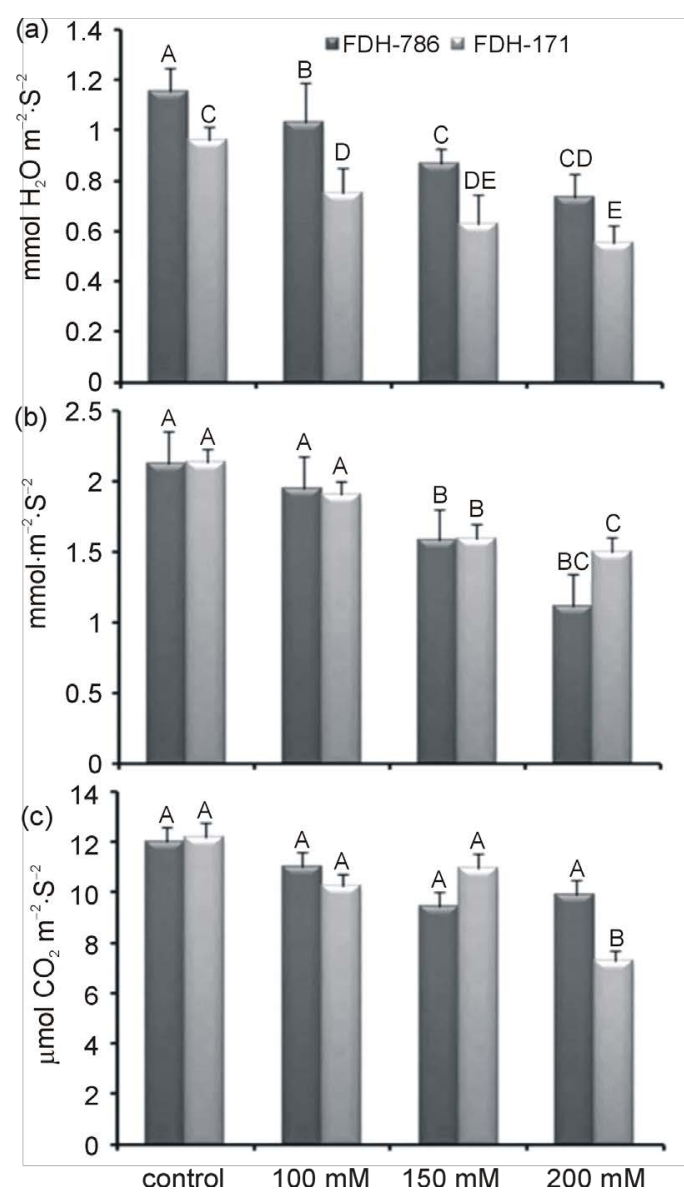

Figure 2. Physiological changes in FDH 171 and FDH 786 under $\mathrm{NaCl}$ stress (a) Transpiration rate (b) Stomatal conductance (c) Photosynthetic rate. Each value is mean of five replicates and vertical bars give standard error of mean. Values with same letter were not significantly different based on Fisher's Least Significant Difference (LSD) test $(\mathrm{P}<0.05)$. 

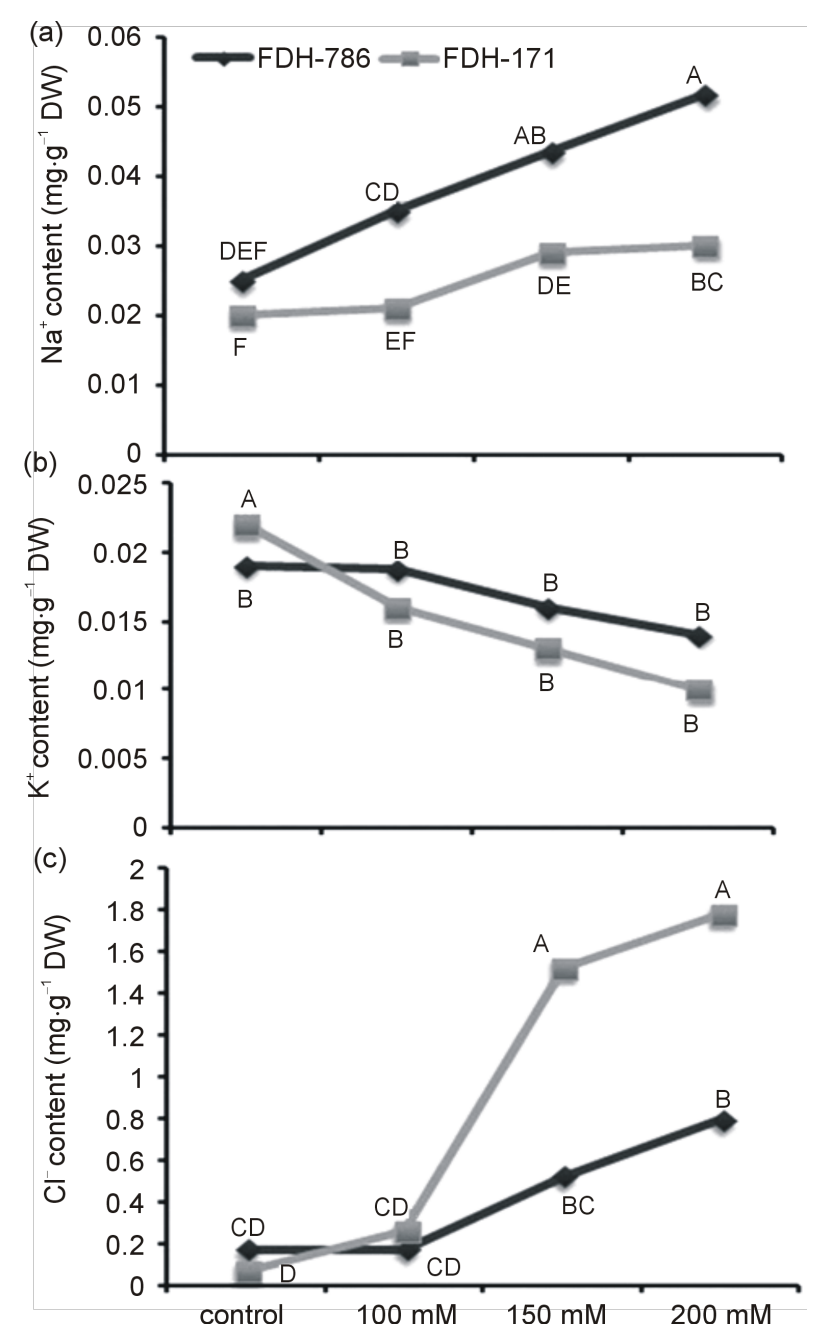

Figure 3. Ion accumulation in FDH 786 \& FDH 171 under $\mathrm{NaCl}$ stress (a) $\mathrm{Na}^{+}$(b) $\mathrm{K}^{+}$(c) $\mathrm{Cl}^{-}$. Each value is the mean of five replicates. Values with same letter were not significantly different based on Fisher's Least Significant Difference (LSD) test $(\mathrm{P}<0.05)$.

\subsection{Molecular Analysis}

\section{PCR Amplification of AtNHX3 Gene}

Salt stressed and control plants of FDH 171 and FDH 786 amplified the AtNHX3 gene through PCR in the form of $195 \mathrm{bp}$ fragment (Figure 4). Interaction terms of ANOVA such as cultivars $\times$ stress treatment and cultivar mean comparison were considered to categorize the most suitable salt stress treatment. Despite highly significant differences between genotypes and parameters investigated, most of the interactions between genotypes and stress treatments were significant between FDH 171 and FDH 786.

\section{Discussion}

Salt treatment affects differently at early plant growth stage as tolerance at germination and seedling development was observed in tomato [2] and Arabidopsis [6]. However, germination and seedling development in cotton is mostly delayed and limited by salinity [18]. Although many of the plant species tolerate salts effects at germination, however, this process is delayed, while the difference within treatments is not significant. This observation classified most of the plants as 'salt tolerant' at this developmental stage [19]. In this study there was $100 \%$ seed germination but hypocotyl was reduced under increased salinity stress. Similar varietal differences in 


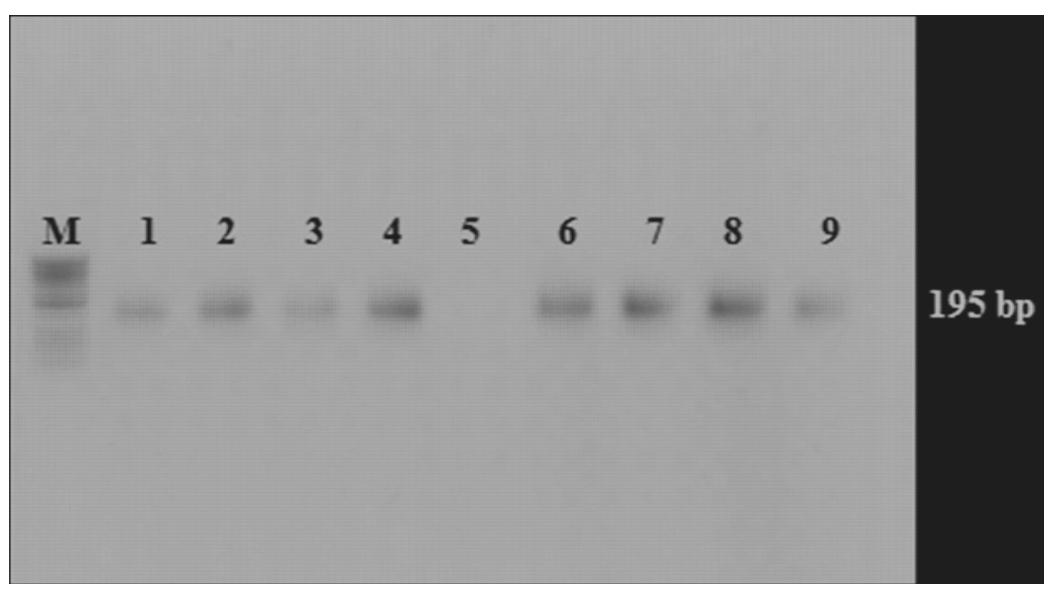

Figure 4. PCR amplification of AtNHX3 gene from cDNA of $\mathrm{NaCl}$ treated and control plants of FDH 786 \& FDH 171; M: 50 bp DNA Ladder (Fermentas); Lane 1 - 4: FDH 786 treated with $\mathrm{NaCl}$ 100, 150, $200 \mathrm{mM}$ \& control respectively; Lane 6 - 9: FDH 171, treated with $\mathrm{NaCl} 100,150,200 \mathrm{mM}$ \& control respectively.

response to salinity have been observed in cotton [4] Available literature states that germination is not affected significantly at saline conditions but seedling development is difficult to continue, so this stage is not sufficient to determine the salt tolerance status of a cultivar [20]. Other factors such as seed viability, dormancy, seed pretreatment and water permeability may complicate the data.

$\mathrm{NaCl}$ with increasing level reduced plant height. Plants were growing normally before $\mathrm{NaCl}$ stress but reduction in plant height after three weeks of salt stress is the clear indication of difference of stress on plants after normal growth. Similar observation of plants' height reduction at different salt stress levels was reported in cotton [21] and other species, so it is suggested that decline in plant height could be a possible sign of salt tolerance or sensitivity. Salt stress resulted in reduction of fresh and dry biomass at the higher rate of $\mathrm{NaCl}$ such as 200 $\mathrm{mM}$. This observation was in correlation with other seedling growth parameters because higher concentration of salts in growing media allows more solute suction and their accumulation to toxic level within plant tissues. This would cause the physiological water deficit which may be the basis of reduction in plant growth and biomass [22].

Lower values of relative leakage ratio in case of salt tolerant genotypes, suggests the accumulation of ion content in leaves play key role in physiological mechanism. Generally, ABA, act as operating mechanism to trigger the signal from roots to other plant parts and thus signal for lower water potential declines transpiration rate with increasing salinity [23]. This study shows correlation with previous reports that salt stress reduces photosynthesis associated with other physiological markers i.e. stomatal conductance and transpiration rate [5]. Leaf water content is reduced under salt stress as the water flow within plants is restricted at organ, tissues or cellular levels. This would lead to close the stomata to conserve the water status in plants [7]. Therefore, stomatal conductance is maintained under lower water potential in resistant genotypes under high saline growing medium. Under mild stress or for a tolerant genotype, stomatal conductance may protect plants by enhancing water use efficiency and plants will save energy and maintain their physiological and biochemical processes even after observing decline in growth [8].

Salt inclusion is one of the principal mechanisms which impair the osmotic adjustment due to accumulation of inorganic ions and particularly $\mathrm{Na}^{+}$and $\mathrm{Cl}^{-}$to the toxic levels within plants through transpiration stream. This study shows that accumulation of $\mathrm{Na}^{+}$and $\mathrm{Cl}^{-}$was increased and $\mathrm{K}^{+}$was decreased as concentration of $\mathrm{NaCl}$ was increased. Generally, those plants having high affinity for $\mathrm{K}^{+}$uptake, transporters will have low $\mathrm{Na}^{+}$uptake. Similar results have been observed in other reports [10] [24]. Nevertheless, the magnitude of deleterious effects of salts on plants' development differs according to type of species, level and duration of stress and number of exposures.

Recent studies suggest that the molecular and metabolic responses of plants' perceived under multiple stresses are distinctive and this cannot be generalized from plant response to the individual stress. Literature is available regarding genes expressing and its adaptations in response to saline environments [12] [25]. Now it is required to correlate these changes in gene expression with physiological processes [13]. 
PCR product of AtNHX3 identified in cDNA of salt stressed and non-stressed plants shows that plants have expression for this gene. AtNHX3 is vacuolar type gene which is localized to vacuolar membrane and $\mathrm{Na}^{+} / \mathrm{H}^{+}$ antiporter that helps to ionic compartmentalization within the cells. Expression of AtNHX3 supplemented the $\mathrm{K}^{+}$ deficiency in $n h x 3$ seedlings which proved that $A t N H X 3$ encodes a $\mathrm{K}^{+} / \mathrm{H}^{+}$antiporter requisite for low $\mathrm{K}^{+}$tolerance, utilization and ion homeostasis in Arabidopsis during seedling development [26].

\section{Conclusion}

Cotton is fairly salt tolerant but its growth and productivity are affected at physiological level which alters molecular responses. Our results provide the information that cotton genotypes FDH 171 \& FDH 786 are tolerant to adoption of salt stress. Hence, it could be used as a line source for incorporation in crop improvement programme for salinity tolerance.

\section{Acknowledgements}

Authors are thankful to Dr Muhammad Yasin Ashraf, Principle Scientist, Nuclear Institute for Agriculture and Biology, Faisalabad, for providing access to IRGA facility and Ayub Agriculture Research Institute Faisalabad for provision of seeds.

\section{References}

[1] Khan, A.H., Singh, A.K., Mubeen, Singh, S., Zaidi, N.W., Singh, U.S. and Haefele, S.M. (2014) Response of Salt-Tolerant Rice Varieties to Biocompost Application in Sodic Soil of Eastern Uttar Pradesh. American Journal of Plant Sciences, 5, 7-13. http://dx.doi.org/10.4236/ajps.2014.51002

[2] Foolad, M. (2004) Recent Advances in Genetics of Salt Tolerance in Tomato. Plant Cell, 76, 101-119. http://dx.doi.org/10.1023/B:TICU.0000007308.47608.88

[3] Hasegawa, P., Bressan, R., Zhu, J.-K. and Bohnert, H. (2000) Plant Cellular and Molecular Responses to High Salinity. Annual Review of Plant Physiology and Plant Molecular Biology, 51, 463-499. http://dx.doi.org/10.1146/annurev.arplant.51.1.463

[4] Khan, N. (2003) NaCl-inhibited chlorophyll synthesis and associated changes in ethylene evolution and antioxidative enzyme activities in wheat. Biologia plantarum, 47, 437-440. http://dx.doi.org/10.1023/B:BIOP.0000023890.01126.43

[5] Chaves, M., Flexas, J. and Pinheiro, C. (2009) Photosynthesis Under Drought and Salt Stress: Regulation Mechanisms From Whole Plant to Cell. Annals of Botany, 103, 551-560. http://dx.doi.org/10.1093/aob/mcn125

[6] Quesada, V., García-Martínez, S., Piqueras, P., Ponce, M. and Micol, J. () Genetic Architecture of NaCl Tolerance in Arabidopsis. Plant physiology, 130, 951-963

[7] Robinson, M., Very, A. and Sanders, D. (1997) How Can Stomata Contribute to Salt Tolerance? Annals of Botany, 80, 387-393. http://dx.doi.org/10.1006/anbo.1996.0435

[8] Mansour, M., Salama, K. and Ali, F. (2005) Cell and Plant Responses to NaCl in Zea mays L. Cultivars Differing in Salt Tolerance. General and Applied Plant Physiology, 35, 29-41.

[9] Ashraf, M. and Harris, P.J.C. (2004) Potential Biochemical Indicators of Salinity Tolerance in Plants. Plant Science, 166, 3-16. http://dx.doi.org/10.1016/j.plantsci.2003.10.024

[10] Maathuis, F.J.M. and Amtmann, A. (1999) K+ Nutrition and Na+ Toxicity: The Basis of Cellular $\mathrm{K}^{+} / \mathrm{Na}^{+} \mathrm{Ratios}^{-}$Annals of Botany, 84, 123-133. http://dx.doi.org/10.1006/anbo.1999.0912

[11] Yang, X., Li F., Zhang, X., Liu, K., Wang, Q., Zhang, C., Liu, C., Zhu, W., Shan, G., Chin, C.K. and Fang, W. (2013) Integration and Characterization of T-DNA Insertion in Upland Cotton. Czech Journal of Genetics and Plant Breeding, 49, 51-57.

[12] Shinozaki, K. and Yamaguchi-Shinozaki, K. (2007) Gene Networks Involved in Drought Stress Response and Tolerance. Journal of Experimental Botany, 58, 221-227. http://dx.doi.org/10.1093/jxb/erl164

[13] Casassola, A., Brammer, S., Soares Chaves, M., Martinelli, J., Grando, M. and Denardin, N. (2013) Gene Expression: A Review on Methods for the Study of Defense-Related Gene Differential Expression in Plants. American Journal of Plant Sciences, 4, 64-73. http://dx.doi.org/10.4236/ajps.2013.412A3008

[14] Rashid, B., Husnain, T. and Riazuddin, S. (2004) In Vitro Shoot Tip Culture of Cotton (Gossypium hirsutum). Pakistan Journal of Botany, 4, 817-823.

[15] Dadkhah, A.R. (2011) Effect of Salinity on Growth and Leaf Photosynthesis of Two Sugar Beet (Beta Vulgaris) Cultivars. Journal of Agricultural Science and Technology, 13, 1001-1012. 
[16] Shahid, M.A., Pervez, M.A., Balal, R., Ahmad, R., Ayyub, C., Abbas, T. and Akhtar, N. (2011) Salt Stress Effects on Some Morphological and Physiological Characteristics of Okra (Abelmoschus esculentus L.). Soil and Environment, 30 , 66-73.

[17] Ryan, P.R., Delhaize, E. and Jones, D.L. (2001) Fuction and Mechanism of Organic Anion Exudation from Plant Roots. Annual Review of Plant Physiology and Plant Molecular Biology, 52, 527-560. http://dx.doi.org/10.1146/annurev.arplant.52.1.527

[18] Qadir, M. and Shams, M. (1997) Some Agronomic and Physiological Aspects of Salt Tolerance in Cotton (Gossypium hirsutum L.). Journal of Agronomy and Crop Science, 179, 101-106. http://dx.doi.org/10.1111/j.1439-037X.1997.tb00504.X

[19] Ashraf, M. and Foolad, M. (2005) Pre Sowing Seed Treatment-A Shotgun Approach to Improve Germination, Plant Growth, and Crop Yield Under Saline and Non Saline Conditions. Advances in Agronomy, 88, 223-271. http://dx.doi.org/10.1016/S0065-2113(05)88006-X

[20] Cherki, G., Ahmed, F. and Khalid, F. (2002) Effects of Salt Stress on Growth, Inorganic Ions and Proline Accumulation to Osmotic Adjustment in Sugar Beet Cultivars. Environmental and Experimental Botany, 47, 39-50. http://dx.doi.org/10.1016/S0098-8472(01)00109-5

[21] Basal, H. (2010) Response of Cotton (Gossypium hirsutum L.) Genotypes to salt stress. Pakistan Journal of Botany, 42, 505-511.

[22] Suriya-Arunroj, D., Supapoj, N. and Toojinda, T. (2004) Relative Leaf Water Content as an Efficient Method for Evaluating Rice Cultivars for Tolerance to Salt Stress. Science Asia, 30, 411-415. http://dx.doi.org/10.2306/scienceasia1513-1874.2004.30.411

[23] Zhang, J. and Davies, W. (1991) Antitranspirant Activity in Maize Plants. Journal of Experimental Botany, 42, 317321.

[24] Cengiz, K., Tuna, A.L., Muhammad, A. and Hakan, A. (2007) Improved Salt Tolerance of Melon (Cucumis Melo L.) by Addition of Proline and Potassium Nitrate. Environmental and Experimental Botany, 60, 397-403. http://dx.doi.org/10.1016/j.envexpbot.2006.12.008

[25] Junior, N., Pereira Nicolau, M., Mantovanini, L. and Zingaretti, S. (2013) Expression Analysis of Two Genes Coding for Trehalose-6-Phosphate Synthase (TPS), in Sugarcane (Saccharum spp.) under Water Stress. American Journal of Plant Sciences, 4, 91-99. http://dx.doi.org/10.4236/ajps.2013.412A3011

[26] Liu, H., Tang, R., Zhang, Y., Wang, C., Li, W. and Zhang, H. (2010) Atnhx3 is a Vacuolar $\mathrm{K}^{+} / \mathrm{H}^{+}$Antiporter Required for Low-Potassium Tolerance in Arabidopsis thaliana. Plant Cell and Environment, 33, 1989-1999. http://dx.doi.org/10.1111/j.1365-3040.2010.02200.x 